\title{
THE URGENCY OF FIQH SIYASAH IN ISLAMIC EDUCATION LEARNING AT MADRASAS AND SCHOOLS
}

\author{
Firman Mansir \\ Universitas Muhammadiyah Yogyakarta, Indonesia \\ Email: firmanmansir@umy.ac.id.
}

\begin{abstract}
This study aims to explain some material descriptions of fiqh siyasah covering four things, namely an explanation of the theory of fiah siyasah in madrasas and schools, factors of figh siyasah, the urgency of fiqh siyasah in madrasas and schools and implementation of figh siyasah in madras and schools. Therefore, this study explores the theory of fiqh siyasah in madras and schools. The author describes the concept of figh siyasah in science, which discusses matters for the affairs of the State. The people of various forms of regulations, laws, and policies. That have been made by leaders who agree with or are in line with the basic teachings of the Sharia in order to realize the benefit of the people. In its implementation, the concept of figh can be seen in madrasas so that a comprehensive level of inculcating these figh values can be achieved. Therefore, this is very important to be taught to average students. If at the previous school level, students were only required to be able to understand the existing doctrines in figh. According to one or more schools, then in this madrasas an understanding of a difference of opinion or view in the prediction of figh learning is given. In addition, students must also be able to implement the science of figh. In everyday life so that, this becomes a form so that the goals of Islamic education are achieved.
\end{abstract}

Keywords: fiqh siyasah, Islamic education, school, madrasa

\begin{abstract}
Abstrak
Penelitian ini bertujuan untuk menjelaskan beberapa uraian materi fiqh siyasah yang meliputi empat hal, yaitu penjelasan tentang teori fiqh siyasah di madrasah dan sekolah, faktor fiqh siyasah, urgensi fiqh siyasah di madrasah dan sekolah serta penerapan fiqh siyasah di madrasah dan sekolah. Oleh karena itu, penelitian ini mengeksplorasi teori figh siyasah di madrasah dan sekolah. Penulis memaparkan konsep fiqh siyasah dalam keilmuan yang membahas tentang urusan kenegaraan. Masyarakat dari berbagai bentuk regulasi, hukum, dan kebijakan. Itu dibuat oleh para pemimpin yang setuju atau sejalan dengan ajaran dasar Syariah untuk mewujudkan kemaslahatan umat. Dalam implementasinya, konsep fiqh dapat dilihat di madrasah sehingga tercapainya taraf yang komprehensif dalam menanamkan nilai-nilai fiqh tersebut. Oleh karena itu, hal ini sangat penting untuk diajarkan kepada siswa pada umumnya. Jika pada jenjang sekolah sebelumnya, siswa hanya dituntut untuk bisa memahami doktrin yang ada dalam fiqh. Menurut satu sekolah atau lebih, maka di madrasah ini diberikan pemahaman tentang perbedaan pendapat atau pandangan dalam prediksi pembelajaran fiqh. Selain itu, siswa juga harus mampu menerapkan ilmu figh. Sehingga dalam kehidupan sehari-hari hal ini menjadi wujud agar tujuan pendidikan Islam tercapai.
\end{abstract}

Kata Kunci: fiqh siyasah, pendidikan Islam, sekolah, madrasah 


\section{A. Introduction}

Islamic religious education is in an educational institution, both madrasas and schools have in common in terms of levels, namely compulsory. Why? As we know that our country has a majority of its population to embrace Islam, and this is also a concrete step by the government of the formation of students who are devout to religion. ${ }^{1}$ Furthermore, the orientation of Islamic religious education is not merely obedient to religion, but also obedient to the state. Therefore, the emergence of fiqh which is an understanding, even more detailed fiqh about state or fiqh siyasah. In the subject of figh siyasah it discusses matters about politics, this is also directly proportional to the subject of citizenship education. However, this fiqh siyasah boils down from the perspective of Islamic political thinkers, if citizenship education is the majority of Western political thinkers.

Politics in this day looks bad in the eyes of the community even though students are new to politics, even though politics is good if it is run by good people. The problem arises how does Indonesia create good people to run the political system well? The political system that we profess is democracy, in fact almost all corners of the world embrace this political system. Of course, this system also has advantages and disadvantages. What are the definitions, factors that influence the fiqh siyasah? As well as the urgency of fiqh siyasah, the view of fiqh siyasah towards the political system of democracy? All will be discussed in the next chapter.

\section{B. Method}

Research method used is literature study. Method of literature study is method of collecting some data obtained through notes, works, or pictures. Thus, discussion or data obtained are the result of exploration from several relevant reading sources. This method can be implemented by first determining the topic to be discussed as the research problem. The data obtained are the result of exploration from books, journals, or related sources related to figh, schools and madrasas, fiqh problems in schools and madrasas, fiqh opportunities in schools and madrasas, and fiqh challenges in schools and madrasas. The technique used to analyze the data in this research is content analysis. Content analysis discusses content in a reading.

\footnotetext{
${ }^{1}$ Nur Hidayat, "Peran dan Tantangan Pendidikan Agama Islam di Era Global," el-Tarbawi, Vol. VIII, No. 2 (2015): 140.
} 
Firman Mansir: The Urgency of State Figh Siyasah in Islamic Education Learning at Madrasas and Schools

\section{Result and Discussion}

Education in the National Education System Law Number 20 Year 2003 is "a deliberate and organized effort to realize the learning process, so students actively increase the capacity associated with religious spiritual forces, self-control, beliefs, noble values, and skills that are education is also a process to change a person's attitude or behavior by carrying out activities in learning, so education is expected to be able to prepare students who are able to plunge into real life. Education is also a process of developing and developing metal and physical learners to form character in order to improve human dignity and with the learning process, character values are behavioral values or student attitudes that are related to one God, another human, nationality, self, which are manifested in a thought, feeling, attitude or action based on religious norms, karma, law, culture, and customs, so that the character values that will be received by students will affect the patterns of thinking, behavior patterns, and attitude patterns which later these attitudes will become a personality of students. ${ }^{2}$ Education in Indonesia, one of which is madrasa education, will then be discussed in this paper, etymologically (in language) which is derived from Arabic language which has the meaning of a place to learn, and the similarity of words in Indonesian means school.

Based on the Minister of Religion Regulations No. 1 of 1964 and No.7 of 1950, Madrasa implies:

1. A place that is used for education that has been set up as a school and also made for Islamic education, becomes the main or the core of the teaching process.

2. An Islamic boarding school or a boarding school that serves education is equivalent to a madrasa.

The growth and development of madrasas in Indonesia cannot be separated from the development of ideas for renewal of mind among Muslims, seeing previously, forms of Islamic education that have developed are traditional Islamic education such as meunasah, rangkang, surau, dayah and pesantren or pondok that are still in development. ${ }^{3}$ traditional system that has not been touched by the modern education system and the education system is still classical. On the 19th and the 20th century

\footnotetext{
${ }^{2}$ Halim Purnomo, Firman Mansir, Tumin, Suliswiyadi, "Pendidikan Karakter Islami pada Online Class Management di SMA Muhammadiyah 7 Yogyakarta selama Pandemi Covid-19," Jurnal Tarbiyatuna, Vol. 11, No. 1 (2020): 91-100

${ }^{3}$ Hasbi Indra, Pendidikan Islam Tantangan dan Peluang di Era Globalisasi (Yogyakarta: Deepublish. 2016), 32.
} 
crews renewed in the field of Islamic religious education and marked by the return of alumni from the Middle East, both from Mecca and Cairo.

Furthermore, education or learning about the theory of fiqh siyasah, fiqh siyasah is tarkib idhafi composed of two words originating from Arabic, the arrays namely the word fiqh and the word siyasah. ${ }^{4}$ Here will be explained about the understanding of each in terms of etymological and terminological views. In language or etymology figh is an understanding. Whereas in term or fiqh terminology is the study of sharia law regarding charity that is made which is derived from the argument of tafsihili (detailed), namely special law taken from the Qur'an and Sunnah. Then fiqh is the study of Islamic law which is sourced from the Qur'an and Sunnah which have been compiled by mujtahid using ijtihad and reasoning methods. Whereas the word سياسة comes from the word ساس, in the dictionary from Lisan al-'Arab it means to take care, rule and take care, so siyasah is to take care of, govern and manage, make policy, lead, government and politics. In terminology Lisan al-'Arab book mentions the purpose of the word siyasah, which is to lead or regulate something using a way that can lead to welfare and benefit. From the explanation above, it is concluded that the fiqh siyasah is knowledge or knowledge which discusses matters for the affairs of the state and the people from various forms of regulation, law, and policies that have been made by leaders who agree or are in line with the basic principles of Sharia in order to realize benefits people.

It is at this madrasa level that the planting of figh values in a comprehensive manner is very important to be taught to students. If at the previous school level, students were only required to be able to understand the doctrines in fiqh, according to one school or more, the period at this madrasa was given an understanding of the difference in a difference of opinion or opinion in fiqh. In additional students should also be able to implement the science of fiqh in daily life. One of them is fiqh of state which must be better understood by students, as Islamic politics becomes a provision in life that must be conveyed to students for community and state life. This provision requires students to remember that they will live in a society and a state.

Political participation is an activity or activities that can be influenced by various factors. First, awareness of the government's political system. This means that here students realize that they have the right of obligation as a citizen of the family.

\footnotetext{
${ }^{4}$ Abdul Jafar, "Fiqh Siyasah dalam Perspektif al-Qur'an dan al-Hadist," Jurnal Pemerintahan dan Politik Islam, Vol. 3, No. 1 (2018): 18-28.
} 
Firman Mansir: The Urgency of State Figh Siyasah in Islamic Education Learning at Madrasas and Schools

Unfortunately, political rights, economic rights, protection rights and others. Second, about how to evaluate and give appreciation to the policies that have been issued and carried out by the government itself. There are several types of political factors:

1. Political communication

Political communication is communication that has political consequences, both actual and potential. This communication can regulate a person's behavior or behavior in an atmosphere in a conflict. Political communication that occurs between the people's government as two parties who implement and use ethics.

2. Political awareness

Political awareness has a bond with one's knowledge, attention and interest in the politics and environment of society, the level of political awareness, which is interpreted as a sign of public awareness that is concerned about the problems that exist in the country.

3. Public knowledge

Public knowledge of the process that has been taken as a decision will determine the direction of a decision that has been taken.

In addition to the above factors, physical factors are also a source, including the availability of public services and facilities. Environmental factors are the unity of objects, conditions, conditions, power, living things, as the place where various kinds of social interaction exist between various institutions and one another. Cultural factors are the basis that will form democracy, both in ethical and civilized ways. This factor is related to attitude, knowledge, perception and trust. ${ }^{5}$

According to Zulkifli Hamid, Nazaruddin Sjamsuddin and Personal Tattoo, the high and low levels of politics are determined by 3 main factors, namely:

1. Educational level,

2. The level of economic life.

3. Facilities that support the continuation of political participation.

For example, there is a system that can help smooth communication between the government and the community. Entering the core of the title of the paper itself is the

\footnotetext{
${ }^{5}$ Asep Suprayogi, "Faktor-Faktor Kurangnya Partisipasi Masyarakat dalam Menggunakan Hak Pilih pada Pilkada Tahun 2017 Ditinjau dari Fiqh Siyasah (Studi pada Kelurahan Fajar Bulan Kecamatan Way Tenong Kabupaten Lampung Barat)," Skripsi (Bandar Lampung: Universitas Islam Negeri Raden Intan Lampung, 2019).
} 
urgency of figh siyasah in madrasas and schools. As we know that urgency is something urgent, important and if needed there must be a solution that is appropriate, fast, effective and efficient. This is not only happening in a country whose scope is broad, even in madrasas and schools there is an urgency towards fiqh siyasah with a smaller scope. Back to the object of this paper are madrassas and schools, in general people know the political system in madrasas and schools are not good enough, from the theory and even the implementation of the political system.

Little will we better understand the political system that our country has adopted. we absolutely think that Indonesia adheres to a political system that is democracy, and that also spreads to madrassas and schools. Next, a definition of democracy will be elaborated a little to make it easier for readers to understand the contents of this section.

Etymologically, democracy comes from the Greek demos (people) and cratos (power), so the word democracy is defined as a system of government from, and, by, for the people. Switching in terminology, democracy according to the views of several experts, including:

1. Joseph A. Schumeter expressed his opinion that democracy is an institutional plan to realize a political decision that gives power to individuals to decide how to compete for people's voices

2. Sidney Hook claims that democracy is a majority agreement which is openly given from the people in the form of a government where policy decisions are important directly and indirectly.

3. Hendri B. Mayo also expressed his opinion that democracy is a policy decision made on the basis of a majority vote, and must be carried out in a conducive condition, democracy is also a political system. ${ }^{6}$

Referring to the presentation of some of the experts above, it can be concluded that democracy is an institutional plan to obtain important political and policy decisions based on the agreement of the majority election of the people in order to win the people's votes and be held in conducive circumstances.

\footnotetext{
${ }^{6}$ Evi Ardianti, "Pemikiran Jimly Asshiddiqie tentang Demokrasi dalam Perspektif Fiqh Siyasah," Skripsi (Bandar Lampung: Universitas Islam Negeri Raden Intan Lampung, 2017).
} 
Firman Mansir: The Urgency of State Figh Siyasah in Islamic Education Learning at Madrasas and Schools

In addition to the explanation above, democracy according to fiqh siyasah will also be described, because the main concept of this paper is fiqh siyasah. Here are some opinions from Islamic political thinkers, the following are:

1. Madjid Khadduri and Muhammad Tahir Azhary explained their opinion that the strength of a country is based on the law that comes from God, but also mentioned using the word "nomocracy" because the designation is a designation that is more suitable than democracy.

2. Taqiyyudin Al-Nabhani in his opinion that there is no place for democracy that is free from sharia, or democracy that is not controlled based on legal instructions. Because the excuse of using the term syara' sovereignty this means that those who deal with and control the aspirations of individuals are not the syara individuals they want.

3. In Al-Hasjimy's view, claiming that the concept of shura can be equated with democracy, but the concept of shura is not necessarily a synonym for democracy.

4. Yusuf al-Qardhawi stated that the contents of this democracy comply with Islamic teachings, mostly in the form of democratic values.

5. Salim Ali al-Bahnasawi also stated the same thing, that there is a positive side to democracy that does not conflict with Islam. The good side is that popular sovereignty exists as long as it does not conflict with Islam. The downside, meanwhile, is the free use of rights that are feared to be misused. ${ }^{7}$

In many of these ideas there is confusion in the study of democracy according to fiqh siyasah which is within the scope of the Islamic religion, some argue that there is no place for democracy, some argue otherwise. However, from the author's own point of view democracy can't be contrary to Islamic teachings, with a note always guided by "amar ma'ruf nahi munkar." In addition, we need to know that "the State of Indonesia is not an Islamic state but a plural state with all kinds of religions, races, cultures and languages." 8

Based on the above explanation about democracy which starts from western political thinkers to Islamic political thinkers, there is a gap of opinion. This could be

\footnotetext{
${ }^{7}$ Ibid., 5

${ }^{8}$ Firman Mansir, "Pendekatan Psikologi dalam Kajian Pendidikan Islam," Psikis: Jurnal Psikologi Islami, Vol. 4, No.1 (2018): 64.
} 
due to background factors, environment, education to religion that they profess to make varied opinions on democracy itself. Because it also allows the reader to take the positive side of democracy itself. Then we have a little more knowledge about the political system adopted by our country Indonesia, and this becomes our initial foundation to continue in a more conical direction.

In a democracy it does not necessarily run well, coupled with the absence of education, especially citizenship education. ${ }^{9}$ In addition, fiqh also has a contribution to the understanding of fiqh siyasah in madrasa, while in Islamic religious education schools it is a part of understanding the fiqh siyasah. In this case the student is solely on the path where he is obedient to the state and religion. At the level of educational institutions stipulated in Law Number 20 Year 2003 concerning the National Education System in Chapter VI Path, Levels and Types of Education, it is clearly written that the level of education is basic education, secondary education and tertiary education. ${ }^{10}$

This precisely must be the focus for our education world so that it will continue to improve itself so that it stays on its goal, namely, to develop the potential of students to become people of faith and to fear God Almighty, to have noble, healthy, knowledgeable, skillful, creative, independent, and become democratic and responsible citizens. ${ }^{11}$ "Democratic citizens" are sentence cuts in the aim of Indonesian education, and this is not nonsense, this is reflected in the political system that we profess, namely democracy. Based on that pretext, it also reinforces that our citizenship, figh and Islamic religious education must be re-evaluated, from various levels of education, because this has an impact on the running of a democratic political system which if not returned to the axis will become the urgency of fiqh siyasah related at madrasas and schools in Indonesia.

If viewed from the madrasa and civic education schools in giving an introduction to the fiqh siyasah and Islamic religious education as a bridge to the introduction of fiqh, with the example of democracy would begin to be eroded by the development of globalization in the days of students in madrasas and schools is a step

\footnotetext{
${ }^{9}$ Muhammad Iqbal, "Urgensi Civic Education dalam Membangun Budaya Demokrasi Menuju Masyarakat Madani Indonesia: Sebuah Pendekatan Fiqh Siyasah," Juris: Jurnal Ilmiah Syariah, Vol. 14, No. 1 (2015): 1-11

${ }^{10}$ Undang-Undang Republik Indonesia Nomor 20 Tahun 2003 tentang Sistem Pendidikan Nasional.

${ }^{11}$ Ibid.
} 
Firman Mansir: The Urgency of State Figh Siyasah in Islamic Education Learning at Madrasas and Schools

that is both to create democratic citizens who obey the state without reducing religious obedience.

This is also supported by the results of Cogan's research, ${ }^{12}$ with the title preparing citizens to be able to develop a democratic political system, the following is the description:

1. Expertise as a global citizen to recognize and approach problems.

2. Expertise to cooperate with other and assume responsibility for their social roles/ obligations.

3. Expertise to understand and accept cultural differences and appreciate them.

4. The capacity to think critically and systematically

5. Willingness to resolve conflicts in a peaceful, non-violent manner

6. Willingness to change lifestyles and basic eating patterns used to protect the environment

7. Expertise to be sensitive to human rights and defend them (such as women, ethnic minorities, etc.)

8. Willingness and capacity to engage in political life at the federal, state, national and international levels.

The above points are very important in the future sustainability of the Indonesian political system, which must start in madrasas and schools. So it is true, the fiqh siyasah is very important, in terms of all directions the direction of fiqh is still important, as we know that fiqh means understanding. Understanding here is certainly not limited by space and time, while there are still people who think then fiqh still exists and will always develop from time to time.

The subject of fiqh certainly has more or less contributed to the understanding of students, which impact is able to implement this understanding in daily life and have benefits for the benefit of the people. ${ }^{13}$ In addition, the democratic political system is certainly not a machine that can work in a short time, the democratic political system works in a long period of time, which is implemented in stages, not only at that time,

\footnotetext{
${ }^{12}$ Ardianti, "Pendidikan Kewarganegaraan (Civic Education) di Negara India," Jurnal Demokrasi, Vol. IV (2005).

${ }^{13}$ Khoirul Falihin, "Studi Kritis Kurikulum Fiqh Siyasah pada Madrasah Aliyah Perspektif Fiqh Khaled Abou el-Fadl," Tesis (Surabaya: IAIN Sunan Ampel, 2011).
} 
but from time to time, and generation to generation to obtain a better democratic political system. $^{14}$

In implementing fiqh siyasah in madrasas and schools, the writer takes a strong example of the election of chairman or leader in an organization. Example the election or the election of the student council president in madrasas and schools. In its implementation, of course there must be good coordination from the student council management of the school principal, relevant teachers and school residents. If reviewed with Functionalist theory owned structurally by Talcott Parsons, the functions required for the activities rather than the system requirements. ${ }^{15}$ Which means, if examined in the implementation of fiqh siyasah in the form of democracy carried out through elections, each individual who must first know their respective functions so that the needs of a system can be met and run well. There are 4 (four) absolute requirements for functions so that a system runs well, namely Adaptation, Goal Attention, Integration, and Latency Patterns Maintenance) or in short with AGIL in the community or school community. ${ }^{16}$ If these 4 (four) functions can be carried out, then a democratic system in the form of an election for the student council president will run well.

In the general there are four steps or stages in order to achieve good general election results, in the holding of elections divided into four stages, namely from planning, implementation, monitoring and evaluation, and the following description:

1. The planning of stage is determined to be five candidates. Then some student council organizers create a team to announce to students that the election will be held. The candidates make a speech one day before the election, so that voters will know more about their candidates, what their vision and mission.

2. The implementation phase is used to determine the daily administrator, then hold elections in each building, so that each building has a block consisting of several rooms, one student one room. Students get a paper with a photo of the nominated candidate, and students have the right to vote, if more than one is deemed invalid. Then, they are asked to fingerprint after the students have cast

\footnotetext{
${ }^{14}$ Latifah Hanum \& Rr. Nanik Setyowati, "Strategi Penanaman Nilai-Nilai Demokrasi pada Siswa di Madrasah Aliyah Negeri Lamongan," Kajian Moral dan Kewarganegaraan, Vol. 1, No. 3 (2013).

${ }^{15}$ Latifah Hanum \& Rr. Nanik Setyowati, "Strategi Penanaman..."

${ }^{16}$ Robi Panggarra, "Konflik Kebudayaan Menurut Teori Lewis Alfred Coser Dan Relevansinya dalam Upacara Pemakaman (Rambu Solo') di Tana Toraja," Jurnal Jaffray, Vol. 12, No. 2 (2014): 291316.
} 
their votes. Elections are not made in the teaching and learning process and are held in one day.

3. Monitoring or monitoring is also carried out in the selection activities, which are carried out by the School Political Security, which will aim to ensure security, so starts the election activity, and they also decide how the general election will be held in each block.

4. Evaluation activities usually follow committee activities such as elections. The committee is tasked with evaluating, then compiling a report on the accountability of the Class Representative Assembly which has a complete picture or vision of these activities. ${ }^{17}$

\section{Conclusion and Recommendation}

\section{Conclusion}

Fiqh siyasah is a science that discusses politics, fiqh siyasah that must be understood by students, such as Islamic politics becomes a provision in life that must be conveyed to students for community and state life. This provision requires students to remember that they will live in a society and a state. Therefore, this subject requires an understanding that is really understood by educators to be conveyed to students with a variety of methods. Factors that influence fiqh siyasah are students' political participation which includes communication, awareness and knowledge about politics. These factors can certainly be created by students on condition that all the elements that support it. Like a table, it will not stand firm if one of its legs is not there, the figh siyasah is also like that, there can not appear a sense of state if the factors mentioned earlier do not exist.

\section{Recommendation}

If viewed from madrasa and civic education schools in giving an introduction to the figh siyasah and Islamic religious education as a bridge to the introduction of fiqh, with the example of democracy would begin to be eroded by the development of globalization that existed. both to create democratic citizens who obey the state without reducing religious obedience. The urgency of fiqh siyasah itself is very important, but not in an urgent situation there must be settlement. The stage of the students is formed

\footnotetext{
${ }^{17}$ Ibid.
} 
through madrasa and this school will be the hope of the state and nation where our political future will be in the future. The implementation of fiqh siyasah certainly varies, one of which is the general election which reflects how our attitudes, students in carrying out a democratic political system. In a simple example the general election of the chairperson of an organization in madrasas and schools is one of the steps in implementing the fiqh of the state comprehensively in order to instill values in community and state life.

\section{E. References}

Ardianti, Evi. "Pemikiran Jimly Asshiddiqie tentang Demokrasi dalam Perspektif Fiqh Siyasah." Skripsi. Bandar Lampung: Universitas Islam Negeri Raden Intan Lampung, 2017.

Ardianti. "Pendidikan Kewarganegaraan (Civic Education) di Negara India." Jurnal Demokrasi, Vol. IV (2005).

Falihin, Khoirul. "Studi Kritis Kurikulum Fiqh Siyasah pada Madrasah Aliyah Perspektif Fiqh Khaled Abou el-Fadl." Tesis. Surabaya: IAIN Sunan Ampel, 2011.

Hanum, Latifah \& Rr. Nanik Setyowati. "Strategi Penanaman Nilai-Nilai Demokrasi pada Siswa di Madrasah Aliyah Negeri Lamongan." Kajian Moral dan Kewarganegaraan, Vol. 1, No. 3 (2013).

Hidayat, Nur. "Peran dan Tantangan Pendidikan Agama Islam di Era Global." elTarbawi, Vol. VIII, No. 2 (2015): 140.

Indra, Hasbi. Pendidikan Islam Tantangan dan Peluang di Era Globalisasi. Yogyakarta: Deepublish. 2016.

Iqbal, Muhammad. "Urgensi Civic Education dalam Membangun Budaya Demokrasi Menuju Masyarakat Madani Indonesia: Sebuah Pendekatan Fiqh Siyasah." Juris: Jurnal Ilmiah Syariah, Vol. 14, No. 1 (2015): 1-11

Jafar, Abdul. "Fiqh Siyasah dalam Perspektif al-Qur'an dan al-Hadist." Jurnal Pemerintahan dan Politik Islam, Vol. 3, No. 1 (2018): 18-28.

Mansir, Firman. "Pendekatan Psikologi dalam Kajian Pendidikan Islam.” Psikis: Jurnal Psikologi Islami, Vol. 4, No.1 (2018): 64.

Panggarra, Robi. "Konflik Kebudayaan Menurut Teori Lewis Alfred Coser dan Relevansinya dalam Upacara Pemakaman (Rambu Solo') di Tana Toraja." Jurnal Jaffray, Vol. 12, No. 2 (2014): 291-316.

Purnomo, Halim, Firman Mansir, Tumin, Suliswiyadi. "Pendidikan Karakter Islami pada Online Class Management di SMA Muhammadiyah 7 Yogyakarta selama Pandemi Covid-19." Jurnal Tarbiyatuna, Vol. 11, No. 1 (2020): 91-100

Suprayogi, Asep. "FaktorFaktor Kurangnya Partisipasi Masyarakat dalam Menggunakan Hak Pilih pada Pilkada Tahun 2017 Ditinjau dari Fiqh Siyasah 
Firman Mansir: The Urgency of State Figh Siyasah in Islamic Education Learning at Madrasas and Schools

(Studi pada Kelurahan Fajar Bulan Kecamatan Way Tenong Kabupaten Lampung Barat)." Skripsi. Bandar Lampung: Universitas Islam Negeri Raden Intan Lampung, 2019.

Undang-Undang Republik Indonesia Nomor 20 Tahun 2003 tentang Sistem Pendidikan Nasional. 